\title{
Pembelajaran Bahasa Arab Kelas VII di Madrasah Tsanawiyah Negeri 4 Sleman Tahun Ajaran 2019/2020
}

\author{
1* Widi Astuti, ${ }^{2}$ Mega Primaningtyas, ${ }^{3}$ Fima Rusfianurti \\ 123STAI Masjid Syuhada Yogyakarta \\ 1*widi280990@gmail.commail,2megaprimaningtyas@hotmail.com
}

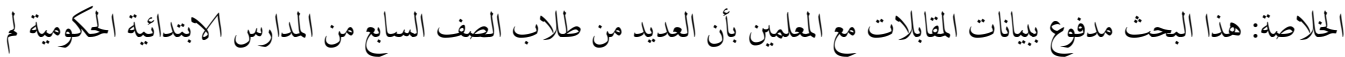

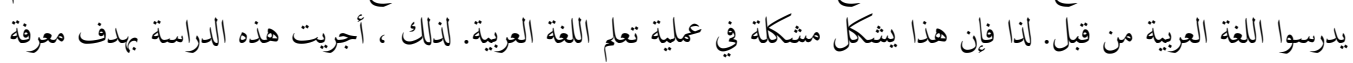

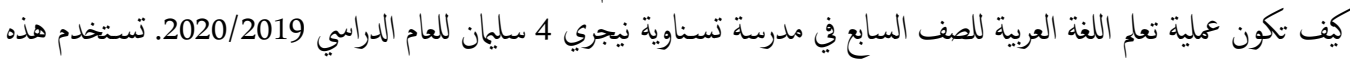

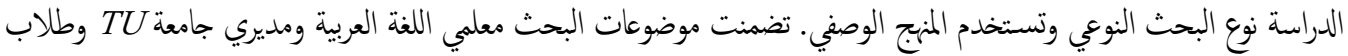

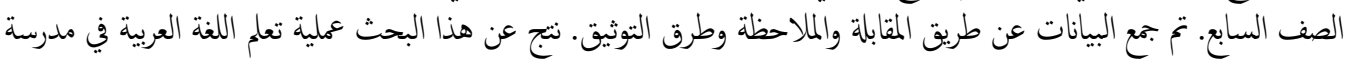

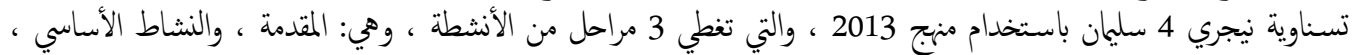

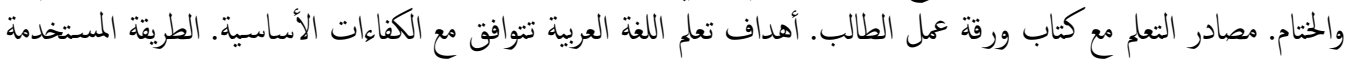

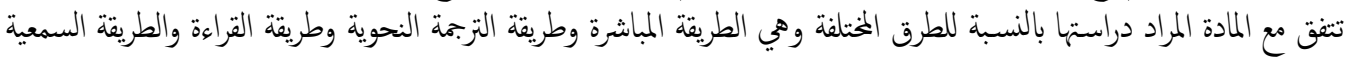

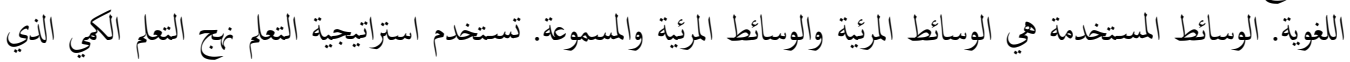

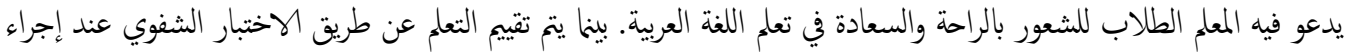

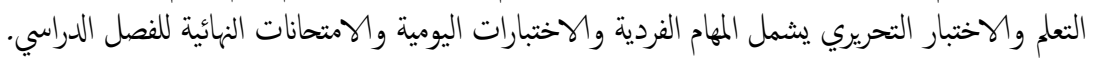

$$
\begin{aligned}
& \text { الكلمات المفتاحية: التعلم ، العربية ، المدرسة }
\end{aligned}
$$

\begin{abstract}
This research was motivated by data from interviews with teachers that many seventh grade students from State Elementary Schools not taught Arabic before. So this makes a problem in the process of learning Arabic. Therefore, this study found that learning Arabic for class VII at Madrasah Tsanawiyah Negeri 4 Sleman is for the $2019 / 2020$ academic year. This study uses a qualitative research type and uses a descriptive approach. The research subjects were Arabic language teachers, TU administrators and seventh-grade students. Data collected by interview, observation and documentation methods. This research is the process of learning Arabic at Madrasah Tsanawiyah Negeri 4 Sleman using the 2013 curriculum, covering three stages of activities: introduction, core activity, and closing and learning resources with the Student Worksheet book. The objectives of learning Arabic are following the Core Competencies. The method used follows the material to be studied, as for the various methods, namely the direct method, the grammatical translation method, the reading method, and the audiolingual method. The media used are visual media and audiovisual media. The learning strategy uses a quantum learning approach in which the teacher invites students to feel comfortable and happy in learning Arabic. At the same time, the evaluation of learning is utilizing an oral test when learning takes place, and a written test includes individual assignments, daily tests and Semester Final Exams.
\end{abstract}

Keywords: Learning, Arabic, Madrasah 


\section{PENDAHULUAN}

Pembelajaran adalah proses interaksi peserta didik dengan pendidik dan sumber belajar pada suatu lingkungan belajar baik lingkungan pendidikan formal maupun nonformal. ${ }^{1}$ Pembelajaran dapat diartikan proses, cara, atau perbuatan menjadikan makhluk hidup belajar. Dalam keseluruhan proses pendidikan di sekolah, kegiatan belajar merupakan kegiatan yang paling pokok. Ini berarti bahwa berhasil tidaknya pencapaian tujuan pendidikan bergantung kepada bagaimana proses belajar yang dialami oleh siswa sebagai anak didik. ${ }^{1}$

Lembaga Madrasah Tsanawiyah Negeri 4 Sleman yang merupakan salah satu lembaga pendidikan islam, sudah semestinya mata pelajaran bahasa Arab di ajarkan, karena bahasa Arab memegang peranan penting dalam bidang ilmu pengetahuan dan kebudayaan islam. Kitab pedoman umat muslim yaitu al- Qur'an dan juga kitab-kitab klasik para ulama seperti imam Syafi'i, imam Ahmad, imam Malik, dan imam Hanafi semua menggunakan bahasa Arab yang sebagian dari kitab-kitab tersebut belum diterjemahkan kedalam bahasa Indonesia.

Jika seorang menguasai bahasa Arab dengan baik, maka dapat dipastikan ia memiliki modal dasar untuk mendalami dan mengembangkan khazanah keilmuan islami seperti fiqh, hadits, tafsir, sejarah, kebudayaan islam, filsafat islam, dan lainlain. ${ }^{2}$ Namun pada realitanya bahwa sebagian besar masyarakat lebih perhatian terhadap bahasa asing lainnya seperti bahasa Inggris daripada bahasa Arab itu sendiri. Padahal telah kita ketahui bahwa bahasa Arabpun merupakan bahasa internasional yang sudah semestinya dikuasai oleh umat Islam dan merupakan bahasa al-Qur'an yang menjadi pedoman umat Islam.

Menurut Abdul Mu'in bahasa Arab di pelajari karena dua alasan. Pertama, karena ia bahasa komunikasi yang harus dipelajari bila kita ingin bergaul dengan pemakai bahasa tersebut. Kedua, karena ia bahasa agama yang mengharuskan pemeluknya mempelajari bahasa Arab untuk kesempurnaan amal ibadahnya, sebab kitab sucinya berbahasa Arab. ${ }^{3}$

Menjadi sebuah tantangan tersendiri bagi guru bahasa Arab atau para pakar bahasa Arab berfikir untuk memberikan solusi alternatif bagaimana cara pembelajaran bahasa Arab yang tepat dan meningkatkan kualitas berbahasa Arab yang masih dianggap sulit oleh sebagian siswa.

\footnotetext{
1 Daryanto, Belajar dan Mengajar, (Bandung: Cv. Yrama Widya , 2010), 1.

2 Ulin Nuha, Metodologi Super Efektif Pembelajaran Bahasa Arab, (Yogyakarta: DIVA Press (Anggota IKAPI), 2012), 79.

${ }^{3}$ Abdul Mu'in, Analisis Kontratif Bahasa Arab dan Bahasa Indonesia (Telaah Terhadap Fonetik dan Morfologi), (Jakarta: Pustaka Al-Husna Baru, 2004), vii
} 
Dalam peristiwa proses belajar mengajar tidak lepas dari unsur pembelajaran seperti: bahan ajar, metode, strategi dan evaluasi, yang mana unsur-unsur tersebut merupakan komponen utama yang harus terpenuhi. Oleh sebab itu guru harus memperhatikan unsur-unsur tersebut. Demikian halnya dengan pembelajaran bahasa Arab di Madrasah Tsanawiyah Negeri 4 Sleman Yogyakarta unsur-unsur tersebut tidak boleh terabaikan.

Mengingat betapa pentingnya bahasa Arab, terlebih bagi umat Islam, sudah semestinya apabila bahasa Arab dijadikan salah satu mata pelajaran yang harus diajaran kepada siswa untuk menjadi dasar pengetahuan, terlebih lagi lembaga formal yang berada di bawah naungan Kementrian Agama termasuk Madrasah Tsanawiyah Negeri 4 Sleman. Mempelajari bahasa Arab memerlukan usaha dan kepandaian khusus karena ia merupakan bahasa kedua bukan bahasa ibu, sehingga hal yang wajar apabila dalam prosesnya seorang guru mengalami kesulitan.

Sebagaimana yang disampaikan oleh bapak Muslikhul Ibad selaku guru mata pelajaran bahasa Arab, pada tanggal 29 juli 2019 di Madrasah Tsanawiyah Negeri 4 Sleman bahwa siswa kelas VII sebagian besar memiliki latar belakang pendidikan yang berasal dari Sekolah Dasar Negeri yang notabene belum mengenal bahasa Arab sebelumnya, namun dalam mengikuti pembelajaran bahasa Arab mereka memiliki antusias yang tinggi. Maka dari itulah peneliti tertarik untuk meneliti lebih lanjut bagaimana proses pembelajarannya, dengan judul penelitian "Pembelajaran Bahasa Arab Kelas VII di Madrasah Tsanawiyah Negeri 4 Sleman Tahun Ajaran 2019/2020".

\section{PEMBAHASAN}

Pada bagian ini peneliti akan memaparkan hasil penelitian yang telah peneliti lakukan yaitu yang berkaitan dengan proses pembelajaran bahasa Arab di Madrasah Tsanawiyah negeri 4 Sleman. Hasil penelitian tersebut diperoleh melalui observasi secara langsung kegiatan pembelajaran bahasa Arab, wawancara dengan yang pihak yang bersangkutan serta pengumpulan dokumen-dokumen yang tersedia.

Pembelajaran yang baik adalah bukan hanya sekedar berlangsung begitu saja, namun memiliki sebuah perencanaan sebelum masuk kedalam kelas. Adapun perencanaan pembelajaran bahasa Arab di Madrasah Tsanawiyah Negeri 4 Sleman adalah sebagai berikut;

Proses pembelajaran bahasa Arab di Madrasah Tsanawiyah Negeri 4 ;Sleman kelas VII C dilaksanakan setiap hari senin jam ke 03 dan 04 yaitu pukul 08.30-09.50 dan hari selasa jam ke 07 yaitu pukul 11.20-12.00 WIB. Satu jam pelajaran berdurasi 40 menit, dalam satu minggu siswa memiliki 3 jam pelajaran untuk mata pelajaran bahasa Arab, sehingga total dalam seminggu berdurasi 120 menit. 
Adapun rincian proses pembelajaran mufradat dengan menggunakan metode langsung adalah sebagai berikut: Pendahuluan dengan Guru membuka pelajaran dengan mengucapkan salam kemudian siswa menjawab dengan serentak dan berdo'a untuk memulai pembelajaran. Guru menanyakan kabar dan menyapa siswa dengan menggunakan bahasa Arab. Guru menanyakan pelajaran hari tersebut dengan menggunakan bahasa Arab. ماذا درسنا الآل ؟ kemudian siswa serentak menjawab.

Guru membuat kesepakatan dengan siswa, supaya lebih kondusif saat pembelajaran. Sebelum memulai pelajaran baru, guru mengawali pelajaran dengan sebuah cerita untuk memotivasi siswa dalam belajar bahasa Arab. Guru mengabsen, kemudian siswa menjawab dengan menyebutkan kosakata beserta artinya. Kosakata yang disebutkan harus berbeda dari kosakata yang sudah disebutkan oleh temannya dan berbeda dengan yang kemaren telah disebutkan, agar siswa tidak mudah lupa dengan kosakata yang sudah dihafal.

Kegiatan inti yaitu Guru berada didepan siswa dan mengumpulkan alat yang akan dipelajari di hari tersebut atau menyiapkan alat-alatnya. Guru mengangkat benda yang akan dikenalkan kepada siswa dengan menyebutkan nama dari alatnya dengan menggunakan bahasa Arab, kemudian siswa menirukan apa yang diucapkan oleh guru hingga sekiranya semua siswa hafal. Dilakukan secara bergantian satu persatu. Setelah anak hafal, guru mengangkat kembali bendanya dengan bertanya maa haadzaa ? atau maa haadzihi ? sesuai dengan bendanya mudzakar atau muannats. Kemudian siswa menjawab dengan dzaalika atau tilka. Misalkan: maa haadzaa ? dijawab, dzaalika qalamun. Dilakukan secara bergantian satu persatu hingga semua kosakata hafal. Sekiranya sudah hafal maka guru menunjuk secara individu untuk menjawabnya. Kemudian siswa menulis kosakata yang ada di papan tulis. Setelah semua anak kenal dengan kosakata tersebut, maka guru memberikan tugas yang ada di LKS. Kemudian di cocokan secara bersama.

Kegiatan Penutup dengan guru memberikan kesempatan kepada siswa untuk bertanya tentang materi yang belum di fahami. Guru menyuruh siswa untuk mengumpulkan buku catatan. Guru menutup pembelajaran dengan do'a dan salam.

Proses pembelajaran al-Istima' adalah sebagai berikut :

a. Pendahuluan

Guru mempersiapkan segala sesuatu yang menunjang proses pembelajaran atau semua peralatan yang akan digunakan yaitu berupa Laptop, speaker, dan LCD. Kemudian mengondisikan peserta didik untuk berdo'a sebelum pelajaran dimulai, menanyakan kabar dengan berbahasa Arab, mengecek atau mengabsen peserta didik yang mana mereka harus menjawab 
dengan menyebutkan kosaka yang sudah diajarkan di hari sebelumnya, memberi nasehat yang sifatnya mendidik peserta didik dan membuat kesepakatan selama proses pelajaran berlangsung untuk memperhatikan apa yang di jelaskan oleh guru.

b. Kegiatan inti

Pada kegiatan inti, guru menyalakan laptop dan menyalakan video yang kemudian anak-anak memperhatikan percakapan atau isi kosakata yang ada di video tersebut. Guru mengulanginya empat kali supaya anak-anak dapat memahami apa yang ada di video. Setelah dilakukan empat kali, guru menunjuk siswa untuk menyebutkan kosakata apa yang didapatkan, secara bergantian satu persatu. Kemudian siswa mencatat di buku tulis masing-masing semua kosakata yang diperoleh dan dikumpulkan. Pada tahap akhir guru menjelaskan isi video tersebut kemudian menulis semua kosakata di papan tulis dengan tetap menyalakan video, dan siswa menulis yang di ada di papan tulis.

c. Penutup

Pada kegiatan penutup, guru selalu memberikan kesempatan untuk bertanya kepada siswa yang belum memahami materi yang telah diajarkan. Kemudian mengumpulkan buku catatan guna mengecek catatan siswa dan melihat tulisan Arab siswa yang akan dijadikan bahan evaluasi, bagaimana guru menindaklanjutinya. Dan yang terakhir berdo'a.

Proses pembelajaran qawa'id adalah sebagai berikut :

a. Pendahuluan

Pada proses pembelajaran di jam pertama di Madrasah Tsanawiyah Negeri 4 Sleman selalu melafalkan Asmaul Husna secara bersama- sama sebelum memulai pelajaran, dilakukan setiap hari supaya semua siswa hafal. Karena setoran Asmaul Husna dijadikan sebagai persyaratan pengambilan ijazah kelulusan. Setelah membaca Asmaul Husna guru membuka pelajaran dengan salam dilanjutkan berdo'a, kemudian menanyakan kabar dengan menggunakan bahasa Arab. Sebelum mulai pelajaran guru sedikit menjelaskan materi yang sebelumnya kurang lebih 10-15 menit.

b. Kegiatan inti

Pada kegiatan inti, guru menjelaskan tentang pola/bentuk/wazan materi tentang fi'il, guru menuliskan di papan tulis fi'il-fi'il baru, merubah fi'il Madhi ke fi'il mudhari', cara mengartikan setiap fi'il-nya guru memberikan contoh kalimat kemudian siswa menebak arti dari fi'il tersebut. Setelah sekiranya siswa hafal dan paham maka guru memberikan tugas mengartikan 
dari bahasa Indonesia ke bahasa Arab atau sebaliknya dari bahasa Arab ke bahasa Indonesia. Setiap slesai menjelaskan dan memberikan tugas, guru menyuruh siswa mencatat yang ada di papan tulis dan mengumpulkan buku catatan. Guru berusaha membuat siswa tidak bosan dan tidak menjadi beban dalam mempelajari bahasa Arab, maka sesekali guru menontonkan sebuah video kepada siswa yang pada saat peneliti melakukan observasi, video yang di tonton yaitu film pendek dengan judul facing the giants yang berdurasi kurang lebih 15 menit. Menonton video dilakukan sesekali bukan setiap pelajaran dan di dilakukan di akhir pelajaran. Setelah selesai menonton kemudian guru menanyakan hikmah apa yang terkandung dalam film tersebut dan menghubungkan film dengan siswa untuk memotivasi dalam belajar bahasa Arab.

c. Penutup

Pada kegiatan penutup, guru memberikan kesempatan untuk bertanya kepada siswa yang belum memahami materi yang telah diajarkan atau kepada siswa ingin menanyakan sesuatu yang berkaitan dengan pelajaran bahasa Arab. Kemudian siswa mengumpulkan buku catatannya masing-masing kepada guru. Dan yang terakhir membereskan peralatan yang digunakan dan menutupnya dengan do'a serta salam. ${ }^{4}$

Tujuan pembelajaran merupakan salah satu hal pokok yang harus diketahui oleh seorang pengajar, karena dengan mengetahui tujuan yang akan dicapai maka seorang pengajar akan mengenali proses yang harus dilakukan dalam mengajar dengan melihat kondisi yang ada.

Tujuan pembelajaran bahasa Arab di Madrasah Tsanawiyah Negri 4 Sleman adalah sebagaimana yang telah diungkapkan oleh guru bahasa Arab, bapak Muslikhul Ibad. "Kalo tujuannya, kita sesuai dengan KI (Kompetensi Inti) dan KD (Kopetensi Dasar) nya itu mba, ada 4 item yaitu:

1) Menghargai dan menghayati ajaran agama yang dianutnya;

2) Menghargai dan menghayati perilaku jujur, disiplin, tanggung jawab, peduli (toleransi, gotong royong), santun, percaya diri, dalam berinteraksi secara efektif dengan lingkungan sosial dalam jangkauan pergaulan dan keberadaannya;

3) Memahami dan menerapkan pengetahuan (factual, konseptual, dan prosedural) berdasarkan rasa ingin tahunya tentang ilmu pengetahuan, teknologi, seni, budaya terkait fenomena dan kejadian tampak mata;

${ }^{4}$ Observasi Pembelajaran Bahasa Arab pada Tanggal 31 Juli 2019, pukul. 07.00-08.20 WIB. 
4) Mengolah, menyaji, dan menalar dalam ranah konkret (menggunakan, mengurai, merangkai, memodifikasi, dan membuat) dan ranah abstrak (menulis, membaca, menghitung, menggambar, dan mengarang) sesuai dengan yang dipelajari di sekolah dan sumber lain yang sama dalam sudut pandang/teori. ${ }^{5}$

Adapun kemahiran atau keterampilan yang ingin dicapainya terdapat empat kemahiran yaitu al-Istima' (mendengarkan), al-Kalam (berbicara), al-Qira'ah (membaca), dan al-Kitabah (menulis). Namun selain itu ada penambahan yaitu qawaid dan mufradat (kosakata). Sebagaimana yang diungkapkan oleh guru bahasa Arab. "Kalo dalam pembelajaran sekolah si hampir sama semuanya mbak, ada 4 keterampilan atau kemahiran itu, plus qowaid dan kosakata, keterampilan istima', kalam, qira'ah, sama kitabah, terus kemudian tambahannya ada qawaid dan kosakata, itu mbak". 6

Dapat dikatakan bahwa tujuan pembelajaran bahasa Arab di Madrasah Tsanawiyah Negeri 4 Sleman sesuai dengan buku pegangan Lembar Kerja Siswa (LKS) yang meliputi kemahiran atau keterampilan mendengarkan, menulis, membaca, berbicara, kosakata dan qawaid. Dengan menguasai keterampilan tersebut maka siswa dapat berbahasa Arab secara aktif maupun fasif juga sebagai alat bantu dalam memahami ilmu-ilmu agama, dan juga tujuan pembelajaran akan lebih mudah tercapai.

Metode pembelajaran merupakan salah satu komponen yang penting yang harus dikuasai oleh seorang guru dalam mengajar untuk dapat menciptakan pembelajaran yang ideal atau kondusif dan juga dapat menarik perhatian siswa. Adapun metode pembelajaran bahasa Arab yang digunakan di Madrasah Tsanawiyah Negeri 4 Sleman yaitu bapak Muslikhul Ibad bervariasi tergantung materi yang akan dipelajari dan kondisi siswa. Metode yang digunakan adalah metode langsung, metode gramatikal terjemah, metode membaca, metode audiolingual, kemudian dengan menggunakan nyanyian, gerakan dan juga terkadang diselingi telling stori, ice breaking, maupun menggunakan game yang berbahasa Arab atau game yang umum. Metode langsung digunakan saat pembelajaran mufradat, untuk memudahkan siswa dalam mengenali makna bahasa ibu dengan langsung melihat bendanya. Metode gramatikal terjemah digunakan menjelaskan tentang kaidah dalam bahasa Arab.

5 Wawancara dengan Bapak Muslikhul Ibad (Pengajar Bahasa Arab), pada Tanggal 27 September 2019, pukul. 10.38 WIB.

6 Wawancara dengan Bapak Muslikhul Ibad (Pengajar Bahasa Arab), pada Tanggal 27 September 2019, pukul. 10.38 WIB. 
Sedangkan dengan metode menyanyi, game, ice breaking, telling stori untuk selingan supaya anak tidak merasa bosan saat mengikuti pelajaran. Pada dasarnya guru berusaha mencoba untuk membuat siswa dalam mengikuti pelajaran bahasa Arab dengan nyaman, senang dan tidak menjadi beban. Adapun pembawaan guru dalam mengajar selalu ceria, tegas namun tidak bersikap galak sehingga siswa tetap menghormati guru namun tetap ada candaan diantara mereka.

Harapan guru dalam pembelajaran bahasa Arab khususnya bagian mufradat, sebenarnya selalu ingin menggunakan metode langsung. Namun yang terjadi dilapangan tidak sesuai, terkadang dibenturkan dengan kondisi siswa yang memang masih buta tentang bahasa Arab atau benar- benar belum mengenal bahasa Arab. Jadi, guru harus menggunakan bahasa ibu guna untuk memahamkan kepada siswa. Sehingga tidak bisa $100 \%$ menggunakan metode langsung. Sebagaimana yang telah diungkapkan oleh bapak Muslikhul Ibad yaitu guru bahasa Arab.

"Kalo saya si sebenarnya hampir setiap materi nggak harus pake metode itu, jadi menyesuaikan, bervariasi kalo saya, dan saya melihat anaknya juga bagaimana, kalo contohnya saya ngajar kelas VII, saya pake metode bernyanyi, mengenalkan kosakata itu dengan nyanyian dan juga kadang dengan menggunakan gambar, bisa juga kan begitu, kadang juga dengan metode langsung, saya harapannya sebenarnya pengin selalu pake metode langsung, untuk kosakata ya, jadi anak-anak itu cukup liat saja, misalkan kitabun, anakanak tau ooo buku tanpa perlu diartikan ini buku, ini qalamun, ini sabburatun, dan seterusnya, penginya seperti itu tapi kan di lapangan kadang-kadang kita dibenturkan dengan anak-anak yang memang masih buta dengan bahasa Arab, kadang-kadang perlu diartikan, o ini penggaris, o ini apa gitu. Jadi saya gantiganti, bervariasi dalam menggunakan metode, tergantung materi dan anaknya juga". 7

Melihat metode pembelajaran yang dilakukan oleh guru bahasa Arab di Madrasah Tsanawiyah Negeri 4 Sleman, menurut peneliti metode tersebut merupakan sebagian dari inovasi dalam penerapan metode pembelajaran. Hal tersebut dilakukan dengan melihat materi materi yang akan dipelajari dan melihat kondisi kemampuan peserta didiknya guna untuk mempermudah siswa dalam mempelajari bahasa Arab.

Media pembelajaran merupakan salah satu komponen yang penting dalam sebuah pembelajaran. Semakin kreatif guru dalam meggunakan media maka

7 Wawancara dengan Bapak Muslikhul Ibad (Pengajar Bahasa Arab), pada Tanggal 27 September 2019, pukul. 10.38 WIB.

Ihtimam: Jurnal Pendidikan Bahasa Arab- Volume 04, Nomor 1, Juni 2021 
ketertarikan siswa terhadap pelajaran semakin meningkat dan menjadikan suasana pembelajaran lebih menyenangkan.

Berdasarakan hasil observasi dan wawancara mendapatkan informasi bahwa media yang sering digunakan dalam pembelajaran bahasa Arab kelas VII di Madrasah Tsanawiyah Negeri 4 Sleman lebih mengutamakan media secara langsung yaitu dengan cara membawa alat langsung yang akan di pelajari. Namun apabila alat yang akan digunakan memang tidak ada maka dengan menggunakan media gambar atau LCD. Selain itu guru menggunakan media papan tulis, spidol, power point atau slide, film dan laptop. Adapun sumber belajar atau buku pegangan yang digunakan di Madrasah Tsanawiyah Negeri 4 Sleman adalah buku Kerja Siswa (LKS). Sebagaimana yang telah diungkapkan oleh guru bahasa Arab.

"Media itu, biasanya saya secara langsung ataupun kalo tidak ada yaa saya bawakan gambar, tapi saya usahakan langsung, misalkan tas, ada tas toh, saya bawakan tas, kemaren itu saya bawakan peralatan-peralatan ke anak-anak, tapi saya usahakan langsung, kecuali memang gak ada, kayak contohnya halaman, sekolah, dan lain-lain, itu kan tidak bisa kita bawa, nah kecuali memang yang seperti itu baru saya menggunakan gambar, kalo rencana saya si misalkan tidak ada gambar saya menggunakan slide, tapi belum, belum saya terapkan, mungkin nanti di bab III".8

Bila dilihat dari penjelasan di atas dapat dikatakan bahwa media pembelajaran bahasa Arab di Madrasah Tsanawiyah Negeri 4 Sleman yang digunakan sangat bervariasi bukan hanya alat-alat yang ada didalam kelas namun semua vasilitas yang ada di sekolah juga. Jadi, media yang digunakan bukan hanya media yang dikategorikan media visual saja namun ada juga media yang dikategorikan media audiovisual.

Strategi pembelajaran merupakan cara-cara yang akan dipilih dan digunakan oleh seorang pengajar untuk menyampaikan materi pembelajaran yang bertujuan untuk memudahkan peserta didiknya dalam memahami materi yang diajarkan. Strategi yang baik yaitu strategi yang dipilih oleh pengajar dengan menyesuaikan kondisi peserta didiknya, bukan peserta didik yang dituntut mengikuti strategi yang dipilih oleh pengajar. Karena dengan menyesuaikan kondisi yang ada maka pengajar akan mengetahui pendekatan apa yang harus digunakan saat mengajar. Sebagaimana yang telah diungkapkan oleh guru bahasa Arab.

"Kalo teknik itu, sebenarnya kalo metode sama teknik hampir mirip ya, kalo teknik lebih spesifik, kalo saya sebenarnya ke anak-anak itu lihat personnya

8 Wawancara dengan Bapak Muslikhul Ibad (Pengajar Bahasa Arab), pada Tanggal 27 September 2019, pukul. 10.38 WIB. 
mbak, lihat kondisi anak, teknik apa yang sesuai gitu kan ya, sebenarnya seperti metode, teknik yang bagus itu kan sesuai dengan anak, bukan anak itu yang menyesuaikan metode atau tekniknya itu, kalo anak si ini yaa seperti ini pendekatannya. Kalo kedepannya saya penginnya bahwasannya anak-anak maju kedepan, yang sudah bisa mbaca atau belum itu belum kelihatan, karena kalo bareng-bareng kan ngikutin aja, belum ngerti person-personnya bagaimana, itu belum saya lakukan, baru rencana kedepannya begitu, untuk mengetahui kemampuan qira'ahnya, cukup satu baris saja atau berapa gitu, anak-anak bisa apa belum". 9

Berdasarkan observasi proses pembelajaran bahasa Arab di Madrasah Tsanawiyah Negeri 4 Sleman dan juga melihat hasil dari wawancara yang telah dilakukan oleh peneliti bahwa model dan strategi pembelajaran yang digunakan adalah dengan pendekatan pembelajaran quantum, yang mana guru tidak menekan siswa baik secara fisik maupun psikis dan juga berusaha mengajak peserta didik dalam mengikuti proses pembelajaran bahasa Arab agar merasa nyaman dan senang.

Tahap akhir pembelajaran bahasa Arab guru melakukan evaluasi dari apa yang telah di dipelajari. Adapun evaluasi yang sudah berjalan di Madrasah Tsanawiyah Negeri 4 Sleman yaitu guru memberikan penugasan berupa tes tertulis dan juga tes lisan. Tes tertulis biasanya guru memperintahkan untuk mengerjakan tugas yang ada di Lembar Kerja Siswa (LKS). Adapun selain itu, tes tertulis juga melalui ulangan harian dan ujian akhir semester. Ulangan harian dilaksanakan setiap per dua bab materi pelajaran selesai, guna mengetahui sejauh mana peserta didik memahami materi yang telah diajarkan. Ujian akhir semester dilaksanakan secara serentak dengan ujian mata pelajaran lainnya. Teknis pelaksanaannya pun berbeda dengan ulangan harian, ujian ini diselenggarakan oleh panitia ujian akhir semester. Sedangkan tes lisan dilakukan saat pembelajaran bahasa Arab berlangsung di dalam kelas, dilakukan dengan cara langsung bertanya kepada siswa setelah dijelaskan.

Adapun evaluasi yang tidak wajib siswa mengikutinya yaitu les bahasa. Karena dengan mengikuti les dapat menambah pemahaman bahasa Arab siswa. Sebagaimana yang telah diungkapkan oleh guru bahasa Arab.

"Kalo evaluasi banyak mbak. Tapi kalo yang sudah berlangsung itu dengan tugas, biasanya yang saya lakukan tugas ada di LKS itu, untuk mengerjakan tugas, kan kelihatan siapa yang sudah bisa apa belum, kalo untuk secara langsung dalam pembelajaran ya saya secara lisan, misalkan hafalkan ini, hafalkan tentang 'adawatul jer, mereka menyebutkan itu secara lisan bisa atau enggak, dan juga kadang-kadang saya memberikan latihan yang ada dipapan

9 Wawancara dengan Bapak Muslikhul Ibad (Pengajar Bahasa Arab), pada Tanggal 27 September 2019, pukul. 10.38 WIB. 
tulis yang berhubungan dengan materi, kalo itu kan masih secara kelompok, nah tapi kalo untuk secara individu biasanya saya menggunakan tugas yang ada di LKS. Selain itu juga ada ulangan harian dan ujian akhir semester. Untuk evaluasi, sekarang alhamdulillah sudah ada les bahasa, disekolah ini, tapi yang jadi masalanya itu yang saya amati anak-anak yang mengikuti itu yang bisa bahasa Arab bukan yang gak bisa bahasa Arab, karena itu les kan tidak wajib".10

Dilihat dari uraian di atas evaluasi pembelajaran bahasa Arab di Madrasah tsanawiyah Negeri 4 Sleman sudah dilakukan sesuai dengan tujuan dan karakteristik materi, karena selain terdapat tes lisan juga terdapat tes tertulis, yang mana melalui tes keduanya tersebut dapat diketahui sejauh mana kemampuan siswa tentang bahasa Arab dan bagaimana untuk menindaklanjutinya.

\section{KESIMPULAN}

Berdasarkan hasil analisis data yang telah penulis lakukan, maka penulis mengambil kesimpulan bahwa proses pembelajaran bahasa Arab di MTs N 4 Sleman menggunakan sumber belajar buku Lembar Kerja Siswa dengan menggunakan kurikulum 2013. Pembelajaran meliputi tiga tahapan yaitu pendahuluan, kegiatan inti, dan penutup. Tujuan pembelajaran adalah sesuai dengan Kompetensi Inti, dan kemahiran yang ingin dicapai adalah al-istima', al-kitabah, al-qira'ah, al-kalam, mufradat dan qawaid.

Metode yang digunakan oleh guru bervariasi sesuai dengan materi yang dipelajari, yaitu dengan metode langsung, metode gramatikal terjemah, metode membaca, metode audiolingual, bernyanyi, dan game. Adapun media yang digunakan adalah yang dikategorikan media visual dan media audiovisual. Kemudian startegi yang digunakan adalah dengan pendekatan pembelajaran quantum yaitu pengajar berusaha membuat pembelajar agar merasa nyaman, dan merasa senang dalam belajar. Sedangkan evaluasi dilakukan dengan menggunakan teknik tes lisan dan tes tertulis.

\section{DAFTAR PUSTAKA}

Abdul Mu'in. 2004. Analisis Kontratif Bahasa Arab dan Bahasa Indonesia (Telaah Terhadap Fonetik dan Morfologi). Jakarta: Pustaka Al-Husna Baru.

Abubakar Muhamad. 1981. Metode Khusus Pengajaran Bahasa Arab. Surabaya: Usaha Nasional.

10 Wawancara dengan Bapak Muslikhul Ibad (Pengajar Bahasa Arab), pada Tanggal 27 September 2019, pukul. 10.38 WIB 
Acep Hermawan. 2013. Metodologi Pembelajaran Bahasa Arab. Bandung: Remaja Rosdakarya.

Ahmad Fuad Effendy. 2012. Metodologi Pengajaran Bahasa Arab. Malang: Misykat Malang.

Ahmad Muhtadi Anshor. 2009. Pengajaran Bahasa Arab Media dan MetodeMetodenya. Yogyakarta: Teras.

Chaidar Alwasilah. 2011. Metodologi Pembelajaran Bahasa Arab. Bandung: Remaja Rosdakarya.

Cholid Narbuko dan Abu Achmadi. 2012. Metodologi Penelitian. Jakarta: Bumi Aksara. Daryanto. 2010. Belajar dan Mengajar. Bandung: Cv. Yrama Widya.

Diah Rahmawati As'ari. Konferensi Nasional Bahasa Arab: "Strategi dan Metode Pembelajaran Bahasa Arab". Universitas Negeri Malang.

Henry Guntur Tarigan. 1990. Pengajaran Kompetensi Bahasa. Bandung: Angkasa.

Kusnan. 2017. Metode Pembelajaran Bahasa Arab: Studi Kasus di Pondok Modern Zam-Zam Muhammadiyah Cilongok Banyumas. Jurnal Kependidikan. IAIN Puswokerto. Volume 5, nomor 1.

Lexy. J. Moleong. 2011. Metodologi Penelitian. Bandung: Remaja Rosdakarya.

M Djunaidi Ghony, Fauzan. 2014. Metodologi Penelitian Kualitatif. Yogyakarta: ArRuzz Media.

Mahmud. 2011. Metode Penelitian Pendidikan. Bandung: Pustaka Setia.

Muhammad Abdullah Ad-duweisy. 2014. Menjadi Guru yang Sukses dan Berpengaruh. Surabaya: Pustaka Elba.

Oemar Malik. 1995. Kurikulum dan Pembelajaran. Jakarta: Bumi Aksara.

Rahmat Iswanto. 2017. Pembelajaran Bahasa Arab Dengan Pemanfaatan Teknologi. Arabiyatuna. Sekolah Tinggi Agama Islam Negeri Curup. Volume 1, nomor 2.

Raswan. 2018. Pengaruh Metode Pembelajaran Eklektik Terhadap Hasil Belajar Bahasa Arab Siswa. Arabiyat. Universitas Islam Negeri Syarif Hidayatullah. Volume 5, nomor 1.

Saiful Sagala. 2010. Konsep dan Makna Pembelajaran. Bandung: Alfabeta

Sugiyono. 2013. Metode Penelitian Kuantitatif dan kualitatif dan R\&D. Bandung: Alvabeta.

Suharsimi Arikunto. 1998. Prosedur Penelitian (Suatu Pendekatan Praktek). Jakarta: Rineka Cipta.

Suja'i. 2008. Inovasi Pembelajaran Bahasa Arab, (Strategi dan Metode Pengembangan Kompetensi). Jakarta: Rineka Cipta.

Sukardi. 2004. Metodologi Penelitian Pendidikan Kompetensi dan Prakteknya. Jakarta: PT Bumi Aksara.

Suparman. 2017. Evaluasi Pendidikan. Yogyakarta: STAIMS Press. 
Sutrisno Hadi. 1983. Metodologi Research II. Yogyakarta: Yayasan Penerbit Fakultas Psikologi UGM.

Ubaid Ridho. 2018. Evaluasi dalam Pembelajaran Bahasa Arab. An-Nabighoh. Universitas Islam Negeri Syarif Hidayatullah. Volume 20, nomor 1.

Ulin Nuha. 2012. Metodologi Super Efektif Pembelajaran Bahasa Arab. Yogyakarta: Diva Press (Anggota IKAPI).

Wa Muna. 2011. Metodologi Pembelajaran Bahasa Arab Teori dan Aplikasi. Yogyakarta: Teras. 